\title{
Genetic parameters of french beef breeds used in crossbreeding for young bull production II. - Slaughter performance
}

\author{
G. RENAND \\ I.N.R.A., Station de Génétique quantitative et appliquée \\ Centre national de Recherches zootechniques \\ F 78350 Jouy-en-Josas
}

\begin{abstract}
Summary
Two sets of slaughter data at constant weight of 3098 and 699 crossbred young bulls from 199 and 42 sires of different French beef breeds, tested in 2 stations, were used to estimate the genetic parameters of carcass criteria (carcass yield, composition, morphology and meat quality). Composition criteria included fattening scores and fat and muscle contents estimated by dissection of the 11th rib. Carcass morphology was estimated by carcass length, beef conformation criteria (fleshiness score, thigh compactness) and by rib eye area. Meat quality was measured on the longissimus dorsi muscle (shearing force, $\mathrm{pH}$ and water loss). Genetic parameters were computed from paternal and residual components of variances and covariances estimated in mixed models by HENDERson's method 3.

Only dressing percentage showed non-homogeneous coefficients of heritability between the 2 data sets : .27 and .69. Mean coefficients of heritability were .27 for fattening scores, .27 for beef conformation criteria and .51 for carcass length. Coefficients of heritability were .54 and .50 for carcass fat and muscle contents, .33 for rib eye area, .30 for shearing force, .11 for $\mathrm{pH}$ and .08 for water loss. The genetic coefficients of correlation were quite homogeneous between the 2 files for some groups of variables. There were positive genetic relationships between live fleshiness score and beef conformation criteria of the carcass and between all these criteria and dressing percentage. Growth rate during fattening was slightly opposed to these criteria of beef conformation and yield. While in both data sets fatness developed later in animals with greater skeletal development and higher birth weight, genetic correlations between carcass composition and the other variables were different between the 2 sets. However it can be concluded that while the simultaneous improvement of growth potential and carcass beef conformation does not theoreticaly require evaluating slaughtered progeny, it should be done to limit the probable increase of fatness precocity following such selection.
\end{abstract}

Key words: Genetic parameters, beef breeds, slaughter performance.

\section{Résumé}

Paramètres génétiques des races à viandes françaises utilisées en croisement pour la production de taurillons

\section{Performances d'abattage}

Deux fichiers de résultats d'abattage à poids constant de 3098 et 699 taurillons croisés, descendants de 199 et 42 pères de différentes races à viande françaises et contrôlés dans 
2 stations, ont été utilisés pour estimer les paramètres génétiques des performances d'abattage (rendement, composition et morphologie de la carcasse, qualité de la viande). La composition de la carcasse est analysée à partir des notes d'état d'engraissement et des teneurs en gras et en muscle estimées à partir de la dissection de la $11^{\mathbf{e}}$ côte. La morphologie de la carcasse est appréhendée par sa longueur et par des critères de conformation bouchère (note de charnure, compacité de la cuisse et de la surface du muscle long dorsal). Sur ce muscle des mesures de qualité de la viande ont également été effectuées (force de cisaillement, $\mathrm{pH}$, perte en eau). Les paramètres génétiques ont été calculés à partir des composantes paternelles et résiduelles des variances et covariances, estimées dans des modèles mixtes par la méthode 3 d'HENDERSON.

Seul le rendement ne présente pas de coefficient d'héritabilité homogène entre les 2 fichiers : 0,27 et 0,69 . Les coefficients d'héritabilité moyens sont de 0,27 pour les notes d'état d'engraissement, 0,27 pour les critères de conformation bouchère, 0,51 pour la longueur de la carcasse. Les coefficients d'héritabilité sont de 0,54 et 0,50 pour les teneurs en gras et en muscle de la carcasse, 0,33 pour la surface du muscle long dorsal, 0,30 pour la force de cisaillement, 0,11 pour le $\mathrm{pH}$ et 0,08 pour la perte en eau. Les coefficients de corrélation génétique sont assez homogènes entre les 2 fichiers pour certains groupes de variables. Il apparaît ainsi des liaisons génétiques positives marquées entre le pointage de la charnure en vif et les critères de conformation bouchère de la carcasse et entre tous ces critères et le rendement à l'abattage. La vitesse de croissance pendant l'engraissement est légèrement opposée à ces critères de conformation bouchère et de rendement. Alors que dans les 2 fichiers les dépôts adipeux ont un développement plus tardif chez les animaux à grand développement squelettique et poids de naissance élevé, les corrélations génétiques entre la composition des carcasses et les autres variables sont différentes entre les 2 fichiers. Toutefois à la vue de ces résultats il est possible de conclure que si l'amélioration simultanée du potentiel de croissance et de la conformation bouchère de la carcasse ne nécessite théoriquement pas la réalisation d'un contrôle sur descendants abattus, par contre celui-ci s'avère nécessaire pour limiter l'augmentation prévisible de la précocité des dépôts adipeux à la suite d'une telle sélection.

Mots clés : Paramètres génétiques, races à viande, performances d'abattage.

\section{Introduction}

The development of young bull production in France led some A.I. units to orient their programs to the selection of sires which would improve the butchery aptitudes specific to this type of production. Station progeny testing of young bulls was developed, followed by their slaughter and carcass quality evaluation. Up to now, no estimate of the genetic parameters of these traits in the French beef breeds has been available in France. It is necessary to know these parameters in order to improve selection efficiency and to predict correlated responses in other traits. This latter aspect is highly important since several professionals - the calf producer, calf feeder and butcher - are involved.

The first article on this subject (RENAND, 1985) estimated the genetic parameters of live performance from data gathered in these progeny testing stations. The aim of the present article is to estimate the genetic parameters of young bull slaughter performance and the relation between slaughter and live performance. These estimates should be very useful to compare the efficiency of different selection methods to improve meat production : performance or progeny testing, live or slaughtered progenies, etc. 


\section{Material and methods}

We used the same animal material as that for estimating live performance during fattening (RENAND, 1985). This material included 3098 crossbred young bulls in a 1st station (Midatest A.I. unit) : 1390 progeny by 65 Blond d'Aquitaine (BA) sires, 403 progeny by 36 Charolais $(\mathrm{Ch})$ sires, 485 progeny by 38 Limousin (Li) sires, 548 progeny by 39 sires of the Coopelso $93(\mathrm{BA} \times \mathrm{Ch} \times \mathrm{Li})$ synthetic sire line and 272 progeny by 21 sires of the synthetic double muscled sire line Inra $95(\mathrm{BA} \times \mathrm{Ch})$. Data on 699 progeny by 42 Charolais sires tested in a 2nd station (Oger A.I. unit) were also analysed. These young crossbred bulls, the progeny of dairy cows (Frisonne cows at Midatest, Frisonne and Normande cows at Oger), were subjected to a high plane of nutrition in feedlots until a final fixed weight was reached. This final weight increased markedly with the annual batches : $515 \mathrm{~kg}$ to 585 and $545 \mathrm{~kg}$, respectively, for the 2 stations. The young bulls from the Midatest unit were slaughtered in 3 different commercial slaughter-houses and those of Oger in only one.

The warm carcasses were weighed less than 1 hour after slaughter. After a half-day of chilling, they were scored and measured by a single technician in accordance with the E.A.A.P. recommendation (DE BoER et al., 1974). For the first 5 Midatest batches, the 11 th rib was taken the day after slaughter. After 3 to 4 days of refrigeration, the rib was dissected into muscle, fat and bone and the meat quality of the longissimus dorsi muscle determined. These measurements were recorded on 1828 young bulls : 656 by 34 BA sires, 215 by 21 Ch sires, 483 by $38 \mathrm{Li}$ sires, 310 by 23 Coopelso 93 sires, and 164 by 17 Inra 95 sires.

Four different types of information were obtained after the young bulls were slaughtered :

- criteria of carcass morphology : fleshiness score (based on 15); thigh compactness (maximum width divided by length); rib eye area measured on the section of the 11 th rib ; measurement of carcass length ; the first 2 criteria are regarded as beef conformation traits by butchers ;

- carcass yield : dressing percentage defined as the ratio warm carcass weight/ live weight at end of fattening. This final live weight was taken after fasting in the morning of the slaughter day;

- composition criteria : carcass muscle and fat contents estimated from results of dissection of the 11 th rib and from weight of perirenal fat, according to the formulae of RoBELIN \& GEAY (1975) ; scores (based on 15) of importance of the development of subcutaneous and channel fat ;

- meat quality criteria : shearing force measured by the Warner-Bratzler apparatus ; ultimate $\mathrm{pH}$; water retention capacity measured by relative weight loss during pressure of a ground sample (GouTEFONGEA, 1966).

The methods of statistical analysis were identical to those used for computing the genetic parameters of live performance (RENAND, 1985). The components of variance were estimated by applying method 3 of HENDERson (HENDERSON, 1953) separately for both stations, and within sire-breed at Midatest. An effect of slaughter house was included in the model for Midatest data. All the variables measured on the carcasses were adjusted for final live weight differences since the slaughter decision aimed for a constant weight. 


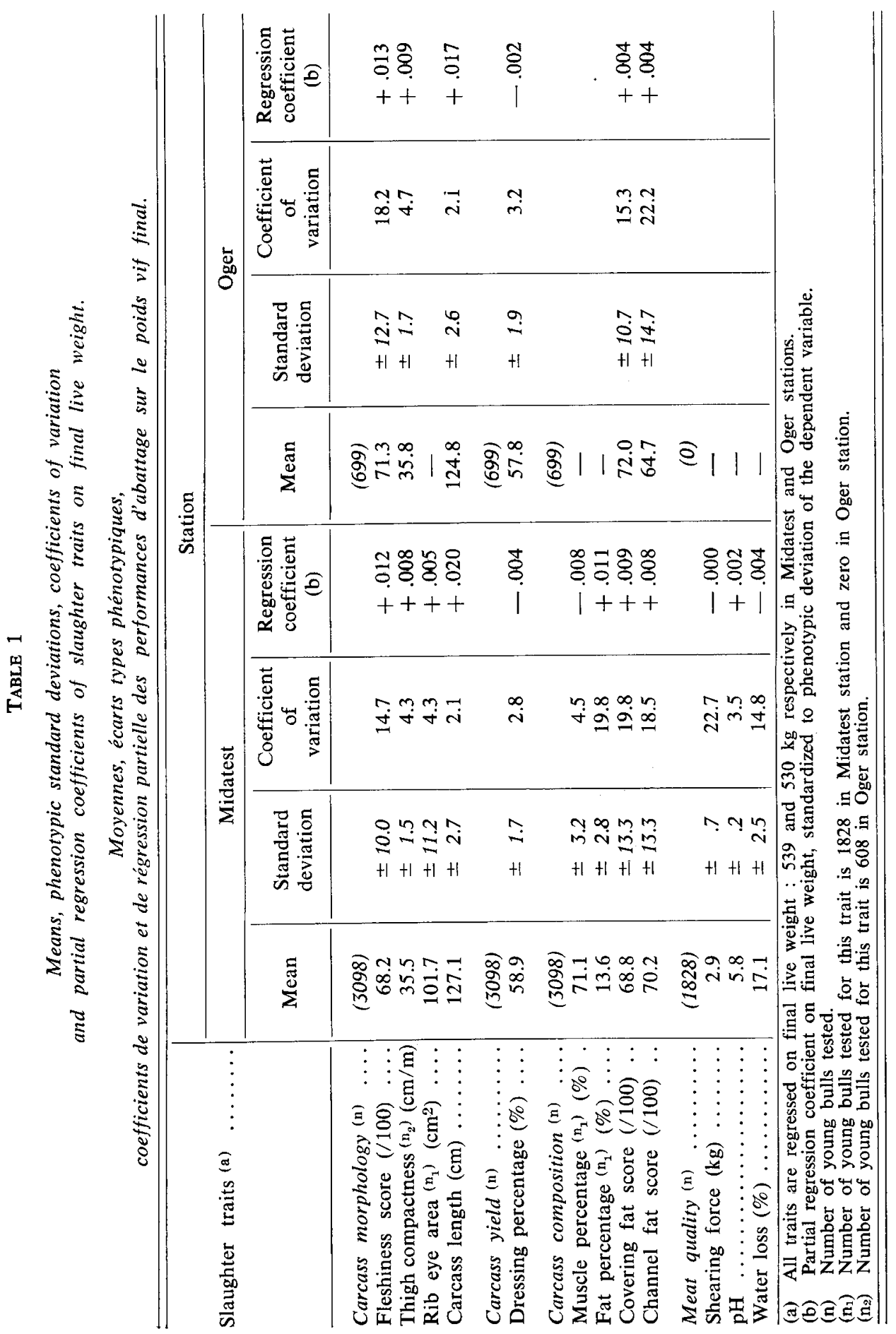




\section{Results and discussion}

\section{A. Means and phenotypic variability}

Among the factors of variation included in the models, we noted in both data sets that the calving parity of the dam had no influence on slaughter performance, while the batch $x$ age-group factor was clearly significant on all variables. At Midatest the slaugther-house had a marked effect on practically all variables. At Oger, maternal breed affected only the fat scores with lower values for young bulls of Normande dams.

Least-squares means, standard deviations and coefficients of phenotypic variation as well as the coefficients of partial regression on final live weight are shown in table 1. Final weight significantly $(\mathrm{P} \leq .01)$ affected most of the variables except dressing percentage at Oger and 2 meat quality criteria (shearing force and $\mathrm{pH}$ ) at Midatest. The coefficients of partial regression observed were in general coherent with biological phenomena related to animal weight gain (increase in size and fatness, reduction of muscle content), but they could not be considered as estimators of these changes due to the decision to slaughter at constant weight. The coefficients of partial regression of dressing percentage were inconsistent with the general increase in this trait observed simultaneously with that of live weight. This certainly expressed the fact that observed variability in final weight was not entirely random. However, due to the low values of these coefficients, adjustment of dressing percentage to the same final weight by regression modified the estimates of these genetic parameters only slightly, contrary to what was found for the morphological criteria.

In both data sets, fatness criteria showed the greatest phenotypic variance. The coefficient of variation of the carcass fleshiness score was entirely comparable to that of the live score (RENAND, 1985), while the coefficient of thigh compactness was clearly lower. Dressing percentage, carcass length and $\mathrm{pH}$ showed the least phenotypic variability at constant live weight.

\section{B. Sire breed effects}

Apart from meat quality criteria, all the variables measured on Midatest carcasses were significantly affected by sire breed. Differences in carcass morphology corresponded to those shown in young bulls before slaughter. The progeny of Inra 95 and Charolais sires had better beef conformation and shorter carcasses than those of Blond d'Aquitaine at the same weight. Classification according to the rib eye area did not follow exactly the same hierarchy and was closer to that of dressing percentage, where the progeny of the double muscled sire line Inra 95 had the highest values and the progeny of the Limousin sire breed the lowest. The results of comparative studies, which included at least 2 of the sire breed types, showed that the differences in dressing percentage between these sire breeds were low, with the Blond d'Aquitaine and Limousin having a slight advantage over the Charolais (AdAms et al., 1973; Bibe et al., 1973, 1976 ; ANDERSEN et al., 1977 ; Koch \& Dikeman, 1977 ; Robelin et al., 1978 ; EveritT et al., 1980 ; Bass et al., 1981 ; Frebling et al., 1982 ; LiboRIUSSEN et al., 1982 ; MENISSIER et al., 1982).

The carcass composition of crossbred Blond d'Aquitaine progeny was clearly leaner than that of the other sire breed types, even the progeny of double muscled sires 


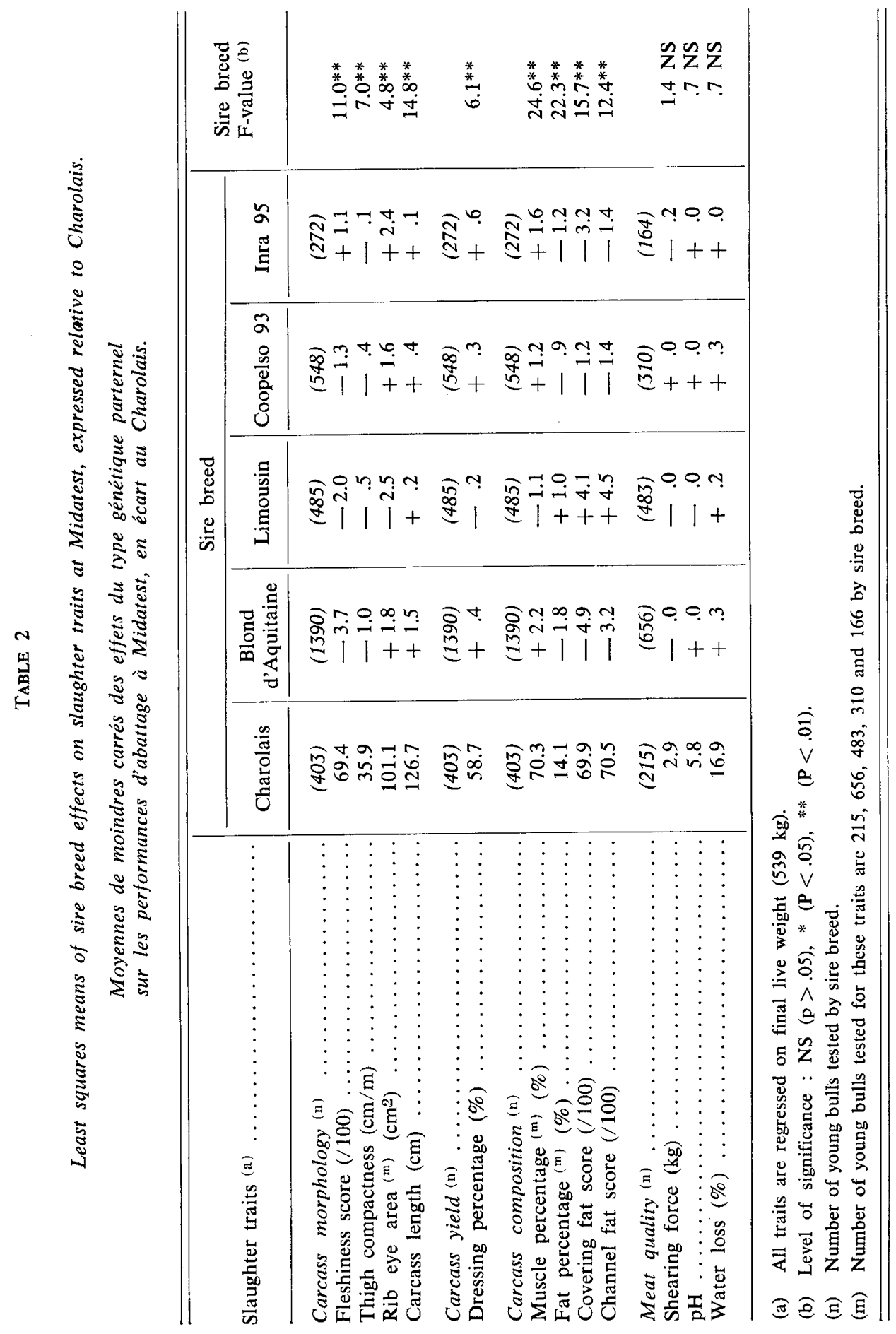


Inra 95. In contrast, Limousin crosses showed the highest fatness, certainly partly due to the decision to slaughter at a fixed weight. The lower growth potential of these young bulls, as well as their lower mature weight, resulted in a more advanced age and stage of maturity at slaughter of Limousin progeny. Miouel et al. (1974) observed similar results at constant weight. The experiments comparing breeds cited above and carried out at a constant age gave variable results between Charolais and Limousin sire breeds while the progeny of Blond d'Aquitaine sires were generally characterized by low fatness.

\section{Heritability coefficients}

Estimates of the coefficients of heritability are shown in table 3. When homogeneous estimates between the 2 data sets were obtained for a group of variables, a « mean " value $\left(\bar{h}^{2}\right)$ was calculated by weighting estimates with the corresponding degrees of freedom of sire effect. Presentation of results is therefore simplified.

TABLE 3

Coefficients of heritability for slaughter traits.

Coefficients d'héritabilité des performances d'abattage.

\begin{tabular}{|c|c|c|c|c|}
\hline \multirow{3}{*}{ Slaughter traits (a) } & \multicolumn{4}{|c|}{ Station } \\
\hline & \multicolumn{2}{|c|}{ Midatest } & \multicolumn{2}{|c|}{ Oger } \\
\hline & Heritability & \pm s.e. & Heritability & \pm s.e. \\
\hline \multicolumn{5}{|l|}{ Carcass morphology } \\
\hline Fleshiness score $\ldots \ldots \ldots \ldots$ & .23 & \pm .05 & .32 & \pm .12 \\
\hline Thigh compactness. & .30 & \pm .05 & .26 & \pm .12 \\
\hline Rib eye area $\ldots . .$. & .33 & \pm .07 & 一 & \\
\hline Carcass length $\ldots \ldots \ldots \ldots$ & .50 & \pm .07 & .54 & \pm .16 \\
\hline Carcass yield & & & & \\
\hline Dressing percentage & .27 & \pm .05 & .69 & \pm .17 \\
\hline \multicolumn{5}{|l|}{ Carcass composition } \\
\hline Muscle percentage . . & .50 & \pm .09 & 一 & \\
\hline Fat percentage $\ldots \ldots \ldots \ldots$ & .54 & \pm .09 & - & \\
\hline Covering fat score $\ldots \ldots \ldots$ & .29 & \pm .05 & .27 & \pm .11 \\
\hline Channel fat score $\ldots \ldots \ldots$ & .23 & \pm .05 & .35 & \pm .12 \\
\hline \multicolumn{5}{|l|}{ Meat quality } \\
\hline Shearing force & .30 & \pm .07 & 一 & \\
\hline pH $\ldots \ldots \ldots \ldots \ldots \ldots$ & .11 & \pm .05 & 一 & \\
\hline Water loss $\ldots \ldots \ldots \ldots \ldots$ & .08 & \pm .05 & 一 & \\
\hline
\end{tabular}

(a) All traits are regressed on final live weight. 
Estimates of the morphological criteria were homogeneous between the 2 data sets. The heritability of carcass beef conformation criteria (fleshiness, thigh compactness) was $\overline{\mathrm{h}}^{2}=.27$ which was not higher than those obtained for fleshiness score on live bulls (RENAND, 1985). Genetic variability of the rib eye area at Midatest $\left(\mathrm{H}^{2}=.33\right.$ ) was slightly less (by .10 point) than the mean of bibliographic data at constant weight (RENAND, 1983). Measurement of carcass length showed a clearly higher coefficient $\left(\bar{h}^{2}=.51\right)$. This value was also higher than the heritability of the live score of skeletal development ( $\overline{\mathrm{h}}^{2}=.15$, RENAND, 1985).

Estimates of the coefficients of heritability of dressing percentage were different between the 2 data sets $\left(\mathrm{h}^{2}=.27\right.$ and .69 , respectively, at Midatest and at Oger). They agreed with the lowest and the highest values, respectively, in the literature (PRESTON \& Willis, 1970 ; RENAND, 1983). The lower value obtained at Midatest was certainly partly related to the multiplicity of slaughter-houses and to a worse control of the slaughter decision. This led to a higher and not completely random variability in final live weight at Midatest as showed by its apparent coefficient of heritability of .27 , while this coefficient was only .08 at Oger. These results emphasize the difficulty in satisfactorily detecting the genetic variability of dressing percentage.

At Midatest, genetic variability in carcass muscle and fat contents was higher than found in growth or beef conformation criteria. The heritability coefficients of muscle and fat contents were $\mathrm{h}^{2}=.50$ and $\mathrm{h}^{2}=.54$, respectively; these were slightly higher (by .10 point) than the mean bibliographic data available at constant weight (RENAND, 1983). In both data sets, subjective scores of the development of the subcutaneous or channel fat showed homogeneous but lower coefficients of heritability $\left(\bar{h}^{2}=.27\right)$ than those of carcass composition estimated from dissection of the 11th rib. Thus, these scores did not show all the genetic variability existing in carcass composition.

Finally, among the meat quality criteria measured at Midatest, only shearing force showed a moderate coefficient of heritability $\left(h^{2}=.30\right)$; this value was identical to the mean of data obtained by Christians et al. (1961), Dubose \& Cartwright (1967), Wilson et al. (1971, 1976), Dinkel \& Busch (1973), Andersen \& LYKKE (1977) and Косн et al. (1982). On the other hand, the other 2 criteria do not seem to be very heritable, at least not under the conditions of measurement. The coefficient of heritability of water loss was only $h^{2}=.08$. For this criterion, Gravert (1962 a) and ANDERSEN \& LYKKe (1977) obtained coefficients of .20 and ENDER (1981) estimates ranged between .18 and .36 for different measurements of the water retention capacity of longissimus dorsi muscle. The coefficient of heritability of ultimate $\mathrm{pH}$ was also low $\mathrm{h}^{2}=.11$. The results in the literature concerning this trait are rare and not clear. Gravert $(1962 \mathrm{~b})$ showed no genetic variability for this trait, while ENDER (1981) obtained a coefficient of .54 for final $\mathrm{pH}$ of longissimus dorsi muscle.

\section{Genetic and phenotypic correlation coefficients}

Estimates of the coefficients of phenotypic $\left(r_{p}\right)$ and genetic $\left(r_{g}\right)$ correlation are shown in tables 4 to 7 . These estimates were not always homogeneous between the 2 data sets but, when they were, a « mean » value $\left(\overline{\mathrm{r}}_{\mathrm{p}}\right.$ and $\overline{\mathrm{r}_{\mathrm{g}}}$ ), weighted by the number of degrees of freedom of the model $\left(\mathrm{r}_{\mathrm{p}}\right)$ or of sire effect $\left(\overline{\mathrm{r}}_{\mathrm{g}}\right)$ was calculated using the Z-transformation to simplify the following presentation of the results. 
Among the criteria of carcass morphology (table 4), fleshiness score and thigh compactness seemed to be highly related phenotypically and genetically $\left(\overline{r_{p}}=+.61\right.$ and $\left.\bar{r}_{g}=+.74\right)$ and opposed to carcass length $\left(\bar{r}_{p}=-.44\right.$ and $\left.\bar{r}_{g}=-.66\right)$. Live fleshiness score was closely related to these two criteria $\bar{r}_{p}=+.51$ and $\bar{r}_{g}=+.75$ ) and opposed to carcass length $\left(\bar{r}_{p}=-.42\right.$ and $\left.\bar{r}_{\mathrm{g}}=-.76\right)$. It seems that the notion of beef conformation (development and compactness of fleshy tissue) was correctly noted by the scorers on the live animal as well as on the carcass. Thus, it is not necessary to slaughter the progeny to evaluate bulls for this trait, and the individual selection of bulls on their own score would be sufficient to improve carcass conformation. The genetic variability of this beef conformation can be detected rather early, as indicated by the coefficients of correlation with the fleshiness score at weaning estimated at Oger $\left(\bar{r}_{g}=+.74\right)$. Finally, the live score of skeletal development correlated less with the criteria of carcass morphology, especially at Midatest : $\overline{\mathrm{r}_{\mathrm{g}}}=+.18$ with carcass length and $\mathrm{r}_{\mathrm{g}}=-.04$ with the criteria of carcass beef conformation while genetic correlations were $: r_{g}=+.61$ and $\bar{r}_{g}=-.40$ at Oger. These results and the low heritability coefficients of the live score of skeletal development (RENAND, 1985) emphasize its poor utility to evaluate carcass shape and size at a constant live weight.

The coefficients of genetic correlation between growth performance (daily gain in feedlot and the negative final age at the end of fattening) and beef conformation criteria (table 4) were slightly negative : $\vec{r}_{\mathrm{g}}=-.22$ at Midatest and $\overline{\mathrm{r}}_{\mathrm{g}}=-.41$ at Oger. They confirmed live results (RENAND, 1985) and showed that simultaneous genetic improvement of these 2 groups of criteria can be obtained only by the use of combined selection indexes. The genetic relations between birth weight and morphological criteria were much less clear. While at Midatest there was independence, at Oger, calves with high birth weight had a slighty better beef conformation than the others.

Among the criteria of carcass composition (table 5), the 2 fat scores were closely interrelated phenotypically and genetically $\left(\bar{r}_{\mathrm{p}}=+.66\right.$ and $\left.\overline{r_{g}}=+.83\right)$. At Midatest they were highly correlated with carcass fat content estimated by dissection of the 11 th rib $\left(\bar{r}_{p}=+.46\right.$ and $\left.\bar{r}_{g}=+.72\right)$. In spite of these relationships, these subjective scores are less useful than dissection results to evaluate genetic differences in carcass fatness due to their lower heritability coefficients. Such results and the costs of the different estimates of the carcass composition must be taken into account in selection programs to improve beef production. It should be noted that the results obtained in the USA showed that heritability coefficients of fat cover thickness were as high as those of weight or percentage of fat trim (Preston \& Willis, 1970 ; Renand, 1983) and showed very high genetic correlations between those fatness criteria : bibliographic mean $r_{\mathrm{g}}=+.81$ (BRACKelsberg et al., 1971 ; Dinkel \& Busch, 1973 ; Dickerson et al., 1974 ; КосH, 1978 ; КосH et al., 1982). To what extent these latter results are related to the animal material used in the studies, which mainly consisted of British beef breeds characterized by high fatness (19 to 25 percent fat trim) and thick subcutaneous fat deposits (12 to $22 \mathrm{~mm}$ fat thickness) is well known.

At Midatest the carcass muscle content estimated by dissection of the 11th rib presented a very strong opposition to fat content $\left(r_{p}=-.95\right.$ and $\left.r_{g}=-.98\right)$ and played a very similar role, even though opposed. This genetic correlation was slightly higher than the coefficients estimated by CunNINGHAM \& BRODERICK (1969), TorREELE \& Slavinski (1970), ANDERSEN \& LYKKe (1977) and ReKLewsKi et al. (1980) at constant weight in dual purpose breeds. It would have been interesting to estimate 


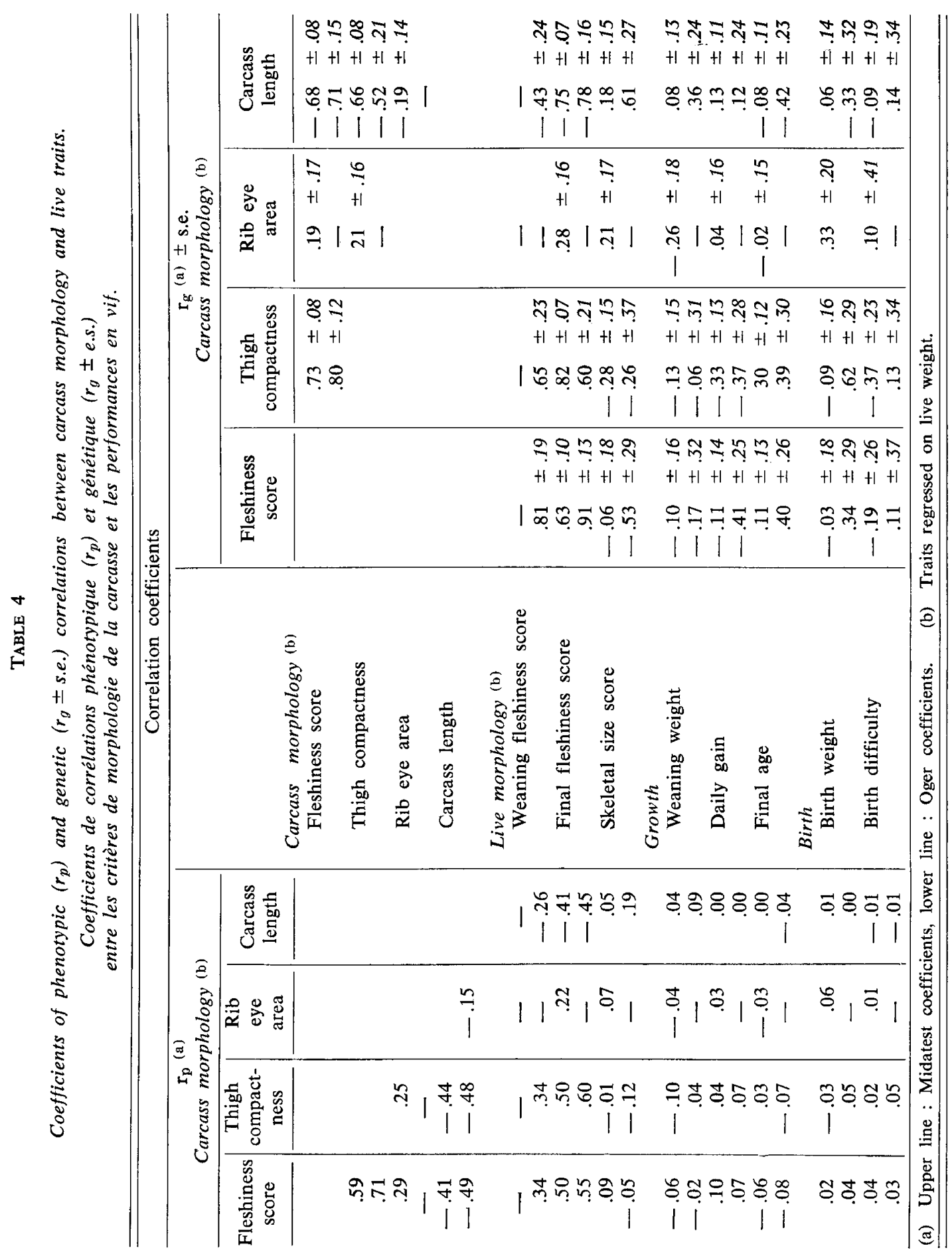


carcass bone content because, while the variability in carcass composition mostly expressed variability in adiposity, there is some variability in the composition of the lean mass as expressed by high coefficients of heritability of the muscle to bone ratio (bibliographic mean $\mathrm{h}^{2}=.63$ ) in the results of ANDERSEN et al. (1974), ANDERSEN \& LYKKE (1977) and AlPs et al. (1981).

TABLE 5

Coefficients of phenotypic $\left(r_{p}\right)$ and genetic $\left(r_{g} \pm\right.$ s.e.) correlations between carcass composition traits.

Coefficients de corrélations phénotypique $\left(r_{p}\right)$ et génétique $\left(r_{g} \pm\right.$ e.s.) entre les critères de composition de la carcasse.

\begin{tabular}{|c|c|c|c|c|c|}
\hline \multirow[b]{2}{*}{$r_{p}(a)$} & Carcass & \multicolumn{4}{|c|}{ Carcass composition (b) } \\
\hline & $\begin{array}{l}\text { Dressing } \\
\text { per- } \\
\text { centage }\end{array}$ & $\begin{array}{c}\text { Muscle } \\
\text { percentage }\end{array}$ & $\begin{array}{c}\text { Fat } \\
\text { percentage }\end{array}$ & $\begin{array}{l}\text { Covering } \\
\text { fat }\end{array}$ & $\begin{array}{c}\text { Channel } \\
\text { fat }\end{array}$ \\
\hline \multicolumn{6}{|l|}{ Carcass yield } \\
\hline Dressing percentage & & $.46 \pm .12$ & $-.39 \pm .13$ & $\begin{array}{r}-.05 \pm .14 \\
-.45 \pm .21\end{array}$ & $\begin{array}{l}-.25 \pm .14 \\
-.32 \pm .22\end{array}$ \\
\hline \multicolumn{6}{|l|}{ Carcass composition } \\
\hline Muscle percentage & .39 & & $-.98 \pm .01$ & $-.72 \pm .08$ & $-.68 \pm .11$ \\
\hline Fat percentage & -.34 & -.95 & & $.75 \pm .08$ & $.69 \pm .10$ \\
\hline Covering fat & -.14 & -.46 & .48 & & $.78 \pm .06$ \\
\hline & -.30 & & - & & $.96 \pm .08$ \\
\hline Channel fat .. & $\begin{array}{l}-.14 \\
-.13\end{array}$ & -.41 & .44 & $\begin{array}{l}.67 \\
.62\end{array}$ & \\
\hline
\end{tabular}

(a) Upper line : Midatest coefficients, lower line : Oger coefficients.

(b) All traits are regressed on final live weight.

The coefficients of correlation between dressing percentage and other traits were of the same sign in both data sets and certainly expressed the same biological processes. However, the magnitude of these relations was greater at Oger than at Midatest. This might be due to the difference in genetic material, sampling errors of estimated coefficients and also to conditions at slaughter. Dressing percentage (table 5) presented a genetic opposition to fat percentage or fat scores $\left(\bar{r}_{\mathrm{g}}=-.22\right.$ and $\overline{\mathrm{r}_{\mathrm{g}}}=-.39$ respectively at Midatest and at Oger). Analysis of the bibliographic results (RENAND, 1983) showed that at constant slaugther weight, the genetic relations between fatness and carcass yield were between about -.3 and +.3 and that at a constant age they were slightly positive. Genetic improvement of dressing percentage would seem to go along with a reduction in bone content (KRÄUSSLICH et al., 1970 ; TorreEle \& Slavinski, 1970 ; ANDERSEN \& LyKKe, 1977) without any large 
changes in fatness. Dressing percentage (table 6) presented a slight genetic opposition to carcass length $\left(\mathrm{r}_{\mathrm{g}}=-.10\right.$ and $\mathrm{r}_{\mathrm{g}}=-.49$ respectively at Midatest and at Oger) and a positive correlation with the criteria of carcass beef conformation $\left(r_{g}=+.32\right.$ and $r_{g}=+.87$ respectively at Midatest and at Oger). At Midatest the genetic coefficient of correlation between dressing percentage and the rib eye area $\left(\mathrm{r}_{\mathrm{g}}=+.47\right)$ was very close to estimates obtained in the Hereford breed by SHELBY et al. (1963), Dinkel \& Busch (1973) (bibliographic mean $r_{g}=+.45$ ) but was lower than estimates obtained in dual purpose breeds by KRÄUSSLICH et al. (1970), ANDERSEN \& LYKKE (1977) (bibliographic mean $r_{g}=+.64$ ). High positive relationships of dressing percentage with live fleshiness score were found at Oger $\left(r_{g}=+.61\right)$ but not at Midatest $\left(r_{g}=+.03\right)$. Finally, the dressing percentage (table 6) was genetically opposed to growth potential during fattening $\left(r_{g}=-.23\right.$ and $r_{g}=-.53$ at Midatest and at Oger), while bibliographic data indicate independence between these 2 traits or at least slight genetic opposition at constant slaughter weight (RENAND, 1983). On the other hand, birth weight showed a notable positive relation with dressing percentage at Oger $\left(r_{\mathrm{g}}=+.33\right)$ but not at Midatest $\left(\mathrm{r}_{\mathrm{g}}=+.07\right)$.

Contrary to the preceding results, estimates of the coefficients of correlation between carcass composition criteria and the other traits were of the same sign in both data sets only for some groups of variables (table 6). Greater skeletal development score was genetically associated with slightly lower fatness $\left(\bar{r}_{\mathrm{g}}=-.25\right)$. This relation certainly expressed later maturity in these large sized bulls. Birth weight showed a slight genetic opposition to adiposity criteria $\left(\vec{r}_{\mathrm{g}}=-.30\right)$. Coefficients estimated by ANDERSEN \& LYKKE (1977) and KOCH et al. (1982) also showed that high birth weight was related to slightly lower carcass fatness. These results confirm that prenatal growth includes important biological processes, not only as regards postnatal growth potential but also in relation to the relative development of tissues and maturity. The relations between the criteria of adiposity and growth during fattening or beet conformation differed clearly between the 2 data sets. While the absence of a relationship between growth and adiposity at Midatest $\left(\bar{r}_{\mathrm{g}}=-.05\right)$ was compatible with most bibliographic data indicating independence, or even genetic opposition, between these traits at constant weight (RENAND, 1983), the positive relation estimated at Oger $\left(\bar{r}_{\mathrm{g}}=+.42\right)$ differed from bibliographic expectation. A more exact estimate of carcass composition is needed in this station to clarify this relationship. The carcass fleshiness score seemed independent of fatness criteria at Midatest $\left(\bar{r}_{k}=+.07\right)$ and slightly opposed at Oger $\left(\bar{r}_{\mathrm{g}}=-.28\right)$. This difference could be partly explained by the different genetic material in the 2 stations. A study of these genetic intra-type relations at Midatest showed that there was a slight opposition between these traits in Charolais and Limousin sire breeds, while this relation was clearly positive in Blond d'Aquitaine. The variability of these results confirms the difficulty of using fleshiness scores for estimating muscle or fat content (KEMPSTER et al., 1982) because they are more related to variations in amount of flesh (muscle + fat) relative to skeleton than to variations in the composition of the flesh (muscle $v$. fat) (DumONT, 1977 ; DuMONT et al., 1980). In France fleshiness is still of economic importance because carcasses with heavy meat mass are valued higher by butchers. Finally, compared to relations with carcass fleshiness, relations of fatness criteria with live fleshiness score $\left(\vec{r}_{\mathrm{g}}=+.53\right.$ and $\bar{r}_{\mathrm{g}}=-.07$ respectively at Midatest and at Oger) showed that the judgement of the scorer was more influenced by the fattening state when he scored the live animal than when he scored the carcass.

The three criteria of meat quality measured at Midatest were genetically independent of each other while, phenotypically, water loss decreased as the $\mathrm{pH}$ increased 


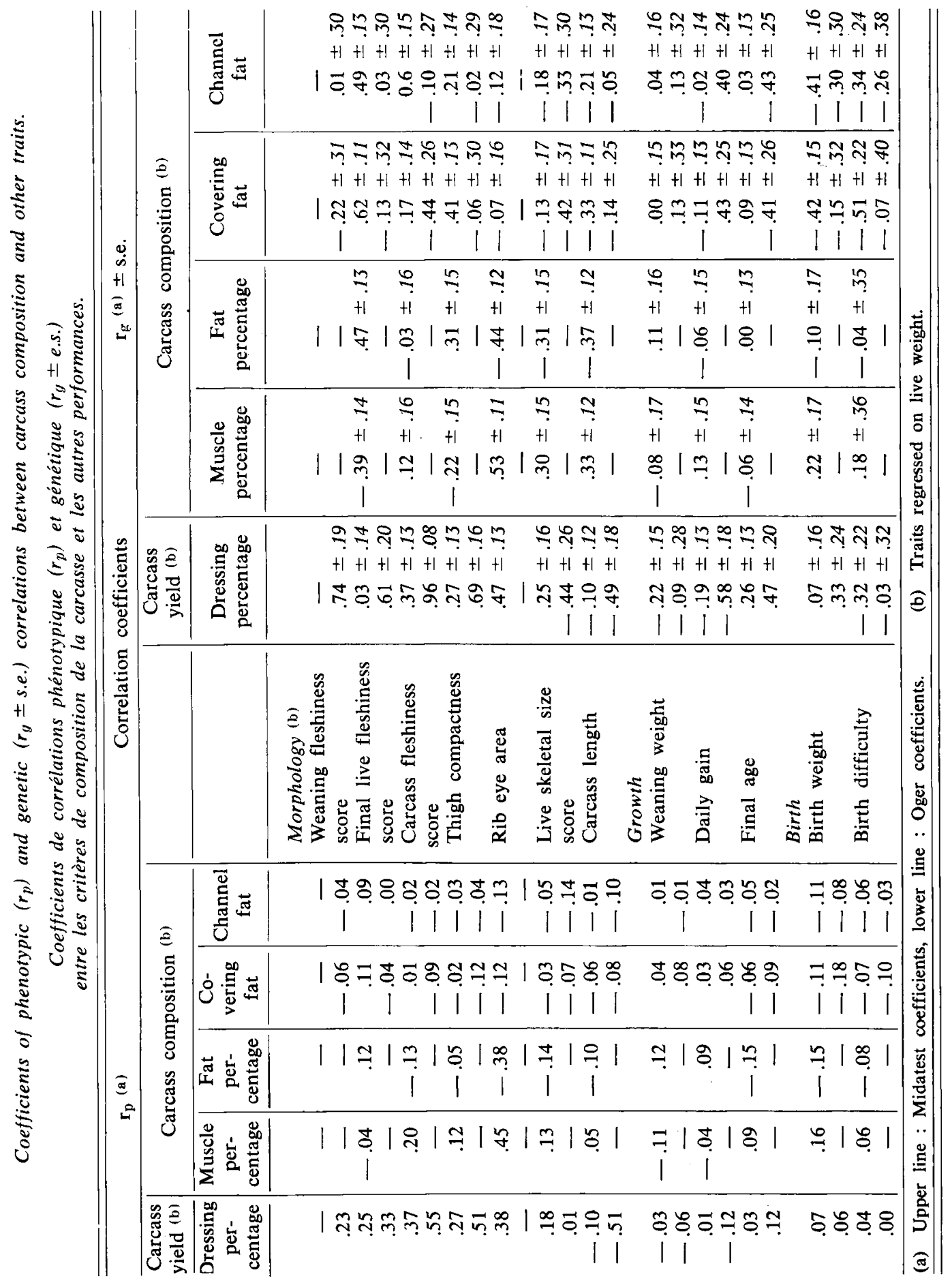


(table 7). The genetic coefficients of correlation between these criteria and carcass fat content showed that a selection against fatness should result in an increase in $\mathrm{pH}$ $\left(r_{g}=-.51\right)$, and in water loss $\left(r_{g}=-.35\right)$. Thus, except for a slightly favorable effect on tenderness $\left(r_{\mathrm{g}}=+.21\right.$ with shearing force) selection against excessively fat carcasses would slightly lower meat quality.

\section{TABLE 7}

Coefficients of phenotypic $\left(r_{p}\right)$ and genetic $\left(r_{g} \pm\right.$ s.e. $)$ correlation between meat quality traits at Midatest.

Coefficients de corrélations phénotypique $\left(r_{p}\right)$ et génétique $\left(r_{g} \pm\right.$ e.s.) entre les critères de qualité de la viande à Midatest.

\begin{tabular}{|c|c|c|c|c|}
\hline \multirow[b]{2}{*}{$\mathbf{r}_{\mathbf{p}}$} & \multicolumn{4}{|c|}{ Meat quality (a) } \\
\hline & $\begin{array}{l}\text { Shearing } \\
\text { force }\end{array}$ & PH & Water loss & $\begin{array}{c}\text { Fat } \\
\text { percentage (b) }\end{array}$ \\
\hline Meat quality & & & & \\
\hline $\begin{array}{l}\text { Shearing force } \ldots \ldots \ldots \ldots \\
\text { pH } \ldots \ldots \ldots \ldots \ldots \\
\text { Water loss } \ldots \ldots \ldots \ldots \\
\text { Fat percentage (b) } \ldots \ldots \ldots\end{array}$ & $\begin{array}{r}-.12 \\
.03 \\
.03\end{array}$ & $\begin{array}{l}-.03 \pm .25 \\
-.45 \\
.02\end{array}$ & $\begin{array}{l}-.06 \pm .22 \\
-.13 \pm .22 \\
-.16\end{array}$ & $\begin{array}{r}.21 \pm .15 \\
-.51 \pm .22 \\
-.35 \pm .25\end{array}$ \\
\hline
\end{tabular}

(a) All traits are regressed on final live weight.

(b) Estimated fat percentage in the carcass.

\section{Conclusion}

This study completes data on the genetic parameters of beef aptitude criteria in the French beef breeds used in crossbreeding. Apart from meat quality criteria, genetic variability in slaughter performance appeared to be rather high. But only part of this variability was detectable when subjective evaluation criteria were used instead of measurements or weights and when conditions of measurements were not sufficiently monitored. The most frequent objective of beef aptitude selection, under French economic conditions, is to simultaneously improve growth rate and carcass conformation; the estimated genetic parameters of this study indicate that this aim may be achieved by selecting sires on their growth rate and fleshiness socre in performance testing stations. But such a selection will be accompanied by correlated increase in early adipose deposits. This maturing precocity will be more evident when a restriction is applied on birth weight due to negative genetic relations between birth weight and fatness. In the production of young meat bulls in France, where increase in carcass weight is desired without increasing fat content at slaughter, such a simple selection method is not enough. It would be useful to test slaughtered progeny and include carcass composition data in the selection criteria to avoid the probable increase in fatness precocity. 


\section{Acknowledgements}

G. Renand wishes to acknowledge both A.I. units (Midatest and Oger) and J. Gaillard (I.T.E.B.) for providing these date and Mrs DAIFUKU for translating the manuscript into English.

Received April 3, 1984.

Accepted July 27, 1984.

\section{References}

Adams N.J., Garrett W.N., Elings J.T., 1973. Performance and carcass characteristics of crosses from imported breeds. J. Anim. Sci., 37, 623-628.

Alps H., Matzke P., Averdunk G., 1981. Schätzung des Fleisch- und Knochengewichtes im Schlachtkörper von Jungbullen der Nachkommenprüfung an Stationen. Z. Tierz. Züchtungsbiol., 98, 197-209.

Andersen B.B., Fredeen H.T., Weiss G.M., 1974. Correlated response in birth weight, growth rate and carcass merit under single-trait selection for yearling weight in beef Shorthorn cattle. Can. J. Anim. Sci., 54, 112-125.

Andersen B.B., Liboriussen T., Kousgaard K., Buchter L., 1977. Crossbreeding experiment with beef and dual-purpose sire breeds on Danish dairy cows. 3. Daily gain, feed conversion and carcass quality of intensively fed young bulls. Livest. Prod. Sci., 4 , 19-29.

ANDERSEN B.B., LYKKE Th., 1977. Growth, feed utilization, carcass quality and meat quality in Danish dual-purpose cattle. Beret. fra Statens Husdyrbrugsfors., 453, Landhusholdningsselskabets forlag, Copenhagen.

Bass J.J., Carter A.H., Johnson D.L., Baker R.L., Jones K.R., 1981. Sire breed comparison of carcass composition of steers from Angus dams. J. Agric. Sci., 97, 515-522.

Bibe B., Frebling J., Menissier F., 1973. Schéma d'utilisation des races rustiques en croisement avec des races à viande. 25th annual meeting, E.A.A.P., Vienna, September 23-26, 1973, $26 \mathrm{p}$. roneo.

Bibe B., Frebling J., Menissier F., Vissac B., 1976. Utilisation des races rustiques en croisement avec des races à viande : exemple de la race Gasconne. Ann. Génét. Sél. Anim., 8, 233-264.

Brackelsberg P.O., Kline E.A., Willham R.L., Hazel L.N., 1971. Genetic parameters for selected beef-carcass traits. J. Anim. Sci., 33, 13-17.

Christians C.J., Henrickson P.L., Morrison R.D., Chambers D., Stephens D.F., 1961. Some factors affecting tenderness of beef. J. Anim. Sci., 20 (Abstr.).

Cunningham E.P., Broderick T., 1969. Genetic and environmental parameters of growth and carcass traits in dual purpose cattle. Ir. J. Agric. Res., 8, 397-416.

De Boer H., Dumont B.L., Pomeroy R.W., Weniger J.H., 1974. Manual on E.A.A.P. reference methods for assessment of carcass characteristics in cattle. Livest. Prod. Sci., 1, 151-164.

Dickerson G.E., Künzi N., Cundiff L.V., Koch R.M., Arthaud V.H., Gregory K.E., 1974. Selection criteria for efficient beef production. J. Anim. Sci., 39, 659-673.

Dinkel C.A., Busch D.A., 1973. Genetic parameters among production carcass composition and carcass quality traits of beef cattle. J. Anim. Sci., 36, 832-846.

Dubose L.E., Cartwright T.C., 1967. Relationships among production and carcass traits in cattle. J. Anim. Sci., 26 (Abstr.).

Dumont B.L., 1977. Relations entre la conformation et la composition des carcasses de bovins. Ann. Zootech., 26, 125-129.

Dumont B.L., D'Herlincourt A., Lefebvre J., 1980. Composition anatomique et morphologique des carcasses des bovins. Proc. 26th Eur. Meet. of Meat Res. Work., Colorado Spring., 31 August - 5 September 1980, vol. A, 260-263. 
ENDER K., 1981. Genetische Aspekte zur Fleischbeschaffenheit beim Rind. Tierzucht, 35, 207-210.

Everitr G.C., Jury K.E., Dalton D.C., LANGRidge M., 1980. Beef production from the dairy herd. 4. Growth and carcass composition of straightbred and beef-cross Friesian steers in several environments. N.Z. J. Agric. Res., 23, 11-20.

Frebling J., Bonaiti B., Bibe B., Gillard P., Menissier F., Renand G., 1982. Comparisons between fattening and slaughter performance of Charolais, Limousin, Maine-Aniou and Hereford breeds according to various production. 2nd World Congress on Genetics applied to Livestock Production, Madrid, 4-8 October 1982, 8, 334-339, Editorial Garsi, Madrid.

Goutefongea R., 1966. Etude comparative de différentes méthodes de mesure du pouvoir de rétention de la viande de porc. Ann. Zootech., 15, 291-295.

Gravert H.O., 1962 a. Untersuchungen über die Erblichkeit von Fleischeigenschaften beim Rind. 1. Fläche des Musc. long. dorsi, Wassergehalt, Wasserverbindung, Fettgehalt. Z. Tierz. Züchtungsbiol., 78, 43-74.

GraverT H.O., 1962 b. Untersuchungen über die Erblichkeit von Fleischeigenschaften beim Rind 2. Eiweissgehalt, pH-Wert, Farbe, Muskel Faserstärke, Zartheit. Z. Tierz. Züchtungsbiol., 78, 139-178.

HENDERSON C.R., 1953. Estimation of variance and covariance components. Biometrics, 9, 226-252.

Kempster A.J., Cuthbertson A., Harrington G., 1982. Carcass evaluation in livestock breeding, production and marketing, 306 p., Granada, London.

Косн R.M., 1978. Selection in beef cattle. 3. Correlated response of carcass traits to selection for weaning weight, yearling weight and muscling score in cattle. J. Anim. Sci., 47, 142-150.

Koch R.M., CundifF L.V., Gregory K.E., 1982. Heritabilities and genetic, environmental and phenotypic correlations of carcass traits in a population of diverse biological types and their implications in selection programs. J. Anim. Sci., 55, 1319-1329.

Косн R.M., Dikeman M.E., 1977. Characterization of biological types of cattle. 4. Carcass wholesale cut composition. J. Anim. Sci., 45, 30-42.

Krauslich H., Averdunk G., Gottschalk A., Schmitter W., Schumann H., Schwarz E., 1970. Die Besamungszucht beim Rind in Bayern. Bayer. Landw. Jahrbuch, 47, 3-85.

Liboriussen T., Lauritzen F., Andersen B.B., Buchter L., Sorensen S.E., Klastrup S., KouSGAARD K., 1982. (Krydnings - og produktions - forsog med europaeiske kodracer i og 2) (in Danish). Beret fra Statens Husdyrbrugsfors., 527, Landhusholdningsselskabets forlag, Copenhagen.

Menissier F., Sapa J., Foulley J.L., Frebling J., Bonaiti B., 1982. Comparison of different sire breeds crossed with Friesian cows : preliminary results. C.E.C. seminar, Dublin, April 13-15, 1981, More O'Ferral G.J. (ed.), Beef production from different dairy breeds and dairy beef crosses, 94-137, M. Nijhoff, The Hague.

Miquel M.C., Cavandoli H.E., Skiadaressi R.M., Molinuevo H.A., Joandet G.E., Parodi J.J., Casal J.J., Lopez-Saubidet C., Bidart J.B., 1974. Evaluación de reses de cruzamientos de razas no traditionales con vientre Aberdeen-Angus. Prod. Anim., 5, 190-208.

Preston T.R., Willis M.B., 1970. Intensive beef production. 567 pp., Pergamon Press, Oxford.

Reklewski Z., Karlowicz W., Czlonkowska M., Jankowski W., 1980. (Estimation of the breeding value of bulls as regards their meat performance, on the basis of measurements of correlated traits) (in Polish). Prace i Materialy Zootechniczne, 23, 31-45.

RENAND G., 1983. Analyse de la variabilité de la croissance et de ses composantes chez les bovins, conséquences pour l'amélioration génétique des aptitudes bouchères. Thèse Docteur-Ingénieur sciences agronomiques, I.N.A., Paris-Grignon.

ReNand G, 1985. Genetic parameters of French beef breeds used in crossbreeding, for young bull production. 1. Live performance. Génét. Sél. Evol., 17, 153-170.

Robelin J., Geay Y., Bonaiti B., 1978. Genetic variations in growth and body composition of male cattle. C.E.C. seminar, Ghent, October 11-13, 1977, DE BoER H., MARTIN J. (ed.), Patterns of growth and development in cattle, 443-461, M. Nijhoff, The Hague. 
Robelin J., Geay Y., 1975. Estimation de la composition des carcasses de jeunes bovins à partir de la composition d'un morceau monocostal prélevé au niveau de la $11^{\circ}$ côte. 1. Composition anatomique de la carcasse. Ann. Zootech., 24, 391-402.

Shelby C.E., Harvey W.R., Clark R.T., Quesenberry J.R., Woodward R.R., 1963. Estimates of phenotypic and genetic parameters in ten years of Miles City R.O.P. steer date. J. Anim. Sci., 22, 346-353.

Torreele G., Slavinski T., 1970. A study about the relationships between growth rate, dressing percentage and carcass composition for intensively fattened young bulls. Med. Fac. Lanbouwwet. Risjks Univ. Gent Belgium, 35, 401-408.

Wilson L.L., Stout J.M., Ziegler J.H., Simpson M.J., Varela-Alvarez H., Rugh M.C., WATKINS J.L., 1971. Heritability of live and carcass characters in a crossbred beef herd. J. Heredity, 62, 123-125.

Wilson L.L., McCurley J.R., Ziegler J.H., Watkins J.L., 1976. Genetic parameters of live and carcass characters from progeny of Polled Hereford sires and Angus - Holstein cows. J. Anim. Sci., 43, 569-576. 